\title{
Bergsonian Study: Time Experience According to Adolescence in Mansfield's Stories
}

\author{
Maryam Jafari ${ }^{1}$, Shiva Zaheri Birgani ${ }^{2}$, Mahnaz Soqandi ${ }^{3}$ \\ ${ }^{1} \mathrm{PhD}$ student in Science Research University, Tehran, Iran \\ ${ }^{2}$ Department of English Language and Literature, Boroujerd Branch, Islamic Azad University, Boroujerd, Iran \\ ${ }^{3} \mathrm{MA}$ student in English Literature, English Language and literature Department, Faculty of Humanities, \\ Semnan University, Semnan, Iran \\ Email: marry.jafary@gmail.com
}

\begin{abstract}
:
With the advent of modernism and new philosophical and scientific ideas, the concept of time was treated in a new way. Bergson's philosophy about time had a great influence on modernist writers and artist. One of the writers who were influenced by him is Katherine Mansfield. Therefore we could see Bergson's theory of time used by her in her stories to convert her own messages. Katherine Mansfield was one of these writers that made use of different techniques in her stories in order to show time. She was much influenced by the French philosopher Henri Bergson and made use of his thoughts in her stories. This paper is going to present how Mansfield shows the concept of time in her stories and what strategies she uses to show the inner time and outer time of her characters. The study also wants to show effects of time on her characters and how being in a certain age of life, status and class in society affects the perceiving of time in people. The major concern of these stories is to show the significance of time according to Bergson's linear and subjective theory of time. These stories show how characters experience duration in their mind and how the linear passage of time mainly affects them. The main purpose of this paper is to study the notion of time according to Bergson's linear and subjective time in Mansfield's stories. According to this theory there are two kinds of time, the spatial time and duration (inner time). Reality is only in the duration of individuals and the only way to achieve freedom is through duration.
\end{abstract}

Keywords :

time; Bergson; short story; duration; linear.

\section{Introduction}

One of the first characteristics that strikes us when we turn our attention to conscious existence is its mutability, its fluidity. It is constantly changing. State follows state with amazing rapidity; indeed, the various states themselves are nothing but processes which flow on with a never-ceasing rhythm. In consciousness, I find nothing static. I discover 'that I pass from state to state. I am warm or cold, I am merry or sad, I work or I do nothing, I look at what is around me or I think of something else. Sensations, feelings, volitions, ideas, - such are the changes into which my existence is divided and which color it in turns. I change, then, without ceasing.' Now change presupposes time. It is, in fact, nothing but a temporal process. However change may be defined, it certainly cannot be defined unless time is taken into account (...) So to be conscious, at least in the sense in which the finite individual is conscious, is just to be in time (...). Duration is the stuff out of which conscious existence is made; for a conscious being to exist is to change, and to change is to endure. (527)

The concept of duration is in its most simple presentation qualitative multiplicity or the fusion of this experience of newness with those that follow. What is commonly called "time" isn't duration but a quantified measure of duration that isn't itself derivative of duration but 
specialization (which also gets referred to as "simultaneity"): i.e. what is counted with clock-time. The importance of the concept for Bergson was to not just be able to reference discrete, quantified or quantifiable multiplicity, but continuity, subjective experience and that which escapes extensive forms of measure. The two sides are never truly separate in actuality, but what we reference tends to either privilege one or the other, which for him presents endless problems in how humans explain and reference reality. You don't have ever one without the other. Simultaneity presupposes (requires) duration, but a measure of simultaneity doesn't account for duration. Extensively presupposes (requires) intensively, but measures of extensive multiplicities don't account for qualitative dynamics. Hope this helps.

\section{Methodology}

The concept of time has become a very important matter, especially in the modern times. The dimension of time seems to be attracting great notice, especially more in the modern times. Time is increasingly a key manifestation of the estrangement and humiliation that characterize the modern existence. An interest in time is not new to literature: in the early twentieth century, such an interest was represented in modernist novels and short stories by for instance Virginia Woolf (1882-1942) and William Faulkner (1897-1962).

Writers of these novels reflected in their representation of time a general shift in thinking about literary conventions in general, and therefore also about the concept of time: apart from seeing it only as the abstract, measurable passage of seconds, minutes, hours et cetera, they found new ways of representation and experimented with new techniques. Their actions of breaking up the coherence of their texts and even the sentences, for instance in stream of consciousness writing, in order to represent a more interior, mental experience influenced the representation of time. This was also reflected in the critical discussion of these works: new theories were needed because writers defied the idea of time as standardized and sequentially arranged, and introduced a multiplicity of private, often nonlinear experiences as the new perception of time.

Philosophical theories such as Henri Bergson's idea of durée, time as personal, inner experience which can speed up or slow down, offered new views on the subject which entered the realm of literature, and indirectly also influenced literary criticism. The approaches in literary criticism dealing with time and narrative that have been developed in recent decades can be roughly divided into four groups: the stream-of-consciousness approach, the point of view approach, the narratological approach and the approach which focuses on the temporal in combination with the spatial.

The first and earliest approach to the new representations of time found in twentiethcentury novels is stream-of-consciousness criticism which focuses on the inner world of the character, and is restricted to the phenomenon of stream-of-consciousness writing only. The point of view approach provides an insight into the different voices and their separate contexts (temporal and spatial) in a text, but it is limited by the formal basis of determining the point of view, type of speech and vantage point.

The narratological approach is thorough, but it is also very formal, tracing all the parts of a narrative and placing them back on a linear timeline. Most of the critics agree that focusing on the representation of time and space in narratives, finally, is a potentially fruitful approach. The three other approaches may have yielded valuable insights, but they are not sufficient enough because they are too formal and/or too much based on the idea of linear time; approaches that focus on the representation of space and time, however, unfortunately also still tend to be based on the idea 
of time as linear. In addition, an explanation of how the concept of time is understood is often not given when such approaches are used. A more open view of time can provide a new starting point for analysis, and lead to new insights; Bergson's theory of the inner time provides such an open view.

Plato and Aristotle have their own definitions of time as philosophers. Aristotle defines time as "the permanent condition for converting becoming into being, potentiality into actuality, and imperfection into perfection" (Meyerhoff 27). Having such a view and believing in such a view, helps man to find an excuse in clinging to time as a source of personal happiness and salvation.

\section{Discussion}

Mansfield describes adolescence as a relatively changeable, fairly innocent period, in her characters life. She shows the quality of indetermination and openness that is special to this age in her stories. It is an age in life that, people still have many options open to them. It is a time for trying out new things and new modes of being. Good examples of her teen-age characters in Mansfield's stories are those of "The Garden Party" (1922) and "The Wind blows" (1920) that I will look upon in this part. The first story is "The Garden Party."

This story covers the time-span of one day of the life of the Sheridan family who are rich people. The story begins from morning and ends in the night and the protagonist is Laura the daughter of the family. The Sheridan family is going to have a garden party in that day and they have hired some men to prepare the garden for them.

The mother of the family has decided not to interfere and let her daughters arrange everything. Her sisters ask Laura to go and order the men to put up the marquee. That's because they believe she's artistic. Laura goes while holding a piece of bread and butter in her hand, but when she reaches the men she becomes ashamed for holding it and tries to behave like her mother but she can't. The workmen behave so friendly that Laura recovers soon and feels easy with them. Laura offers a few suggestions but the workers don't agree and in the end they decide to put it against the karakas trees. At first Laura feels disappointed because she wants the trees to be in view, but soon she forgets about everything as she sees one of the workmen smelling a flower. She becomes surprised when she sees this gesture and wishes she could be friends with these men instead of the rich spoiled boys that she is friends with.

In this part it is the first time that Laura thinks about class distinctions and believes they are absurd, and she doesn't feel them. She feels very happy and friendly with the workmen and in order to prove this, she takes a bite of her bread and butter. After this incident Laura's friend Kitty calls and she goes to answer the phone. Laura invites Kitty to lunch and tells her that Mrs. Sheridan (Laura's mother) wants her to wear the hat she wore on last Sunday. After the phone call the florist comes with pots of pink lilies. Laura feels sad because she believes no one ordered so much, but her mother says she ordered them, although she said she would not interfere in anything. This makes Laura irritated. While getting prepared for the party one of the servants brings bad news. A low class young man, who lived in a lane at the other side of the Sheridan's house has got killed in an accident, and left his wife and five children. This shocks Laura so much, that for a moment she believes they should stop the party immediately and thinks everyone will agree with her.

She says her opinion about stopping the party to her sister Jose, but Jose only thinks that it's absurd and silly. Angered, Laura goes to confront her mother and tell her everything. Her 
mother first thinks that one of their own workers has been killed and becomes extremely worried but after Laura tells her the complete story she is relieved and even feels amused about Laura's worry. In order to make Laura forget everything she gives her a new hat and makes her wear it. When Laura brings up the subject again, this time her mother gets angry and says that those people don't expect sacrifice from us and you should not ruin every ones joy. Laura goes to her own room and hopes her mother is right and decides not to think about it until after the party. After lunch everyone is ready for the party to begin. When her brother Laurie arrives Laura rushes to tell him everything. She somehow feels that if he agrees with the others then it is certainly right, but when her brother compliments her on her appearance she forgets everything and doesn't tell him.

After the party the family sits in the marquee having coffee. Her father has also heard about the incident and brings up the subject calling it a horrible affair. Mrs. Sheridan suggests that they should send the dead man's wife a basket full of the things left from the party. Laura thinks it is not a good idea because maybe the woman would feel very bad to take scraps from their party. Anyway they fill the basket and Mrs. Sheridan orders Laura to take the basket herself. Laura starts walking down towards the cottages and feels she can't realize the man's death. She feels that she is full of the party, the laughter and the happiness from there and she has no room for anything else. She crosses the road and enters the lane towards the cottages. Everything seems so dark, there seems to be no light in there and Laura wishes she had put on a coat because her frock shines so much, she also feels ashamed about her hat and wishes she hadn't put it on. She knows that she made a mistake for coming, but it is too late to go back.

She knocks on the door of the house and decides she would give them the basket and immediately leave, because she wants to get away from the place very soon. A small woman opens the door and guides her to the kitchen where the dead man's wife is sitting. The dead man's wife does not seem to understand why Laura is there and just stares at Laura. Laura just wants to go so she leaves the basket and gets out of the kitchen; the woman's sister guides her towards a room where the dead man is. Laura feels that the man is sleeping very peacefully and he is very content. She can't say anything except apologizing for wearing her hat. She gets out of the house and meets her brother at the corner of the lane. She holds her brother and tries to tell him something about life, however she tries nothing comes out but her brother seems to completely understand her and the story ends.

The story is told in the third person point of view, but it mostly takes place in Laura's consciousness, and duration. The position of the narrator is both inside and outside the character. Laura, the central figure of the story, is in the age of adolescence, which is a time for changing and evolution. The insistent desire to experience new things during adolescence could be seen in the following expression from the story, "But still one must go everywhere, one must see everything" (Mansfield 204). This displays the curiosity of adolescence Laura and her brother Laurie, and their need to explore and investigate everything and new things.

In the story Laura is confronted with death for the first time in her life. While this is something quite normal for the rest of the family, she considers them as "heartless." They accuse Laura of being extravagant and they believe that since the death happened in the lower classes it can be dealt with by sending a gift. For Laura it is a new, crushing experience casting a shadow on her day, making her question everything in her life. Laura is thrown from the linear daily routine of her life where there is no change and she is happily living in, into a new life were she has to accept death and the absurdity of life. Patrick D. Morrow (1993) says about this, "This encounter with death, after an afternoon abounding with life and all its pleasures provide Laura with her first lesson about the discrepancy between life's apparent rationality and its actual absurdities" (74). 
Throughout the story we see that she has mixed feelings about social differences. Her internal struggle is about identity, whether to imitate environmental influences or react in a way that is unique to her personality and deep in her mind she knows is right. She is in a kind of duality with herself regarding this issue and she does not know whether she should accept these differences like her family or stay against them. Although she does not accept these differences she has accepted her role in society as a rich person and acts as one. During the story we see that she changes according to circumstances. But at the end of the story when she goes to the dead man's house it has a very serious impact on her, it can be said that crossing the physical space between the partying family in the garden and the desolation of death and poverty across the lane is a minimal but significant journey for Laura.

In fact throughout the story Laura goes on experiencing new things. It is true that while experiencing new things she goes on changing or maturing, but the past Laura remains within her as an unseparating part. This shows the continuity of Laura's duration as Bergson believes that the "evolution" of a living being, implies a "continual" recording of duration, a "persistence" of the past in the present (Creative Evolution 20).

When Laura goes to see the dead man she walks through a "gloomy passage," which symbolizes her journey from childhood to adulthood. When she meets the dead man's wife, she realizes the class distinctions; the dead man's wife is pictured as a not very beautiful person. But the dead man is pictured as someone beautiful and sleeping peacefully. In other words "Laura learns that while poverty is hindrance to beauty death makes boundaries disappear" (Alonso 86). The end of the story shows that a shift has taken place in her consciousness. On the way home she is unable to find the words to tell her brother what she feels, because she has ventured to a wild zone of her own that she cannot explain.

The fact that Laura is in the age of adolescence gives her the time and chance to change her views and mature, and be someone completely different from her family. Just as Bergson believes that "for a consciousness being, to exist is to change, to change is to mature, to mature is to go on creating oneself endlessly" (Creative Evolution 8). At the end of the story although Laura's view changes about life and a new stage begins in her life, and she completely comes out of childhood, it is not mentioned what path she would choose, whether rebel against the social conditions of her society or accept them. So Laura may change or she may not change, however in Bergsonian terms it is impossible to predict how she will change in the future.

The other story that shows adolescence is "The Wind Blows." It is about a young girl called Matilda who is going to enter the world of the adults. According to William New there is no shift in the time of the story and the place alters in the imagination. But the entire action takes place within a single day. The story is divided into two sections, the first part starts with Matilda's waking up to a stormy day. She feels that something bad has happens but then she understands it is only the wind that is blowing and shaking the house. She starts tying her hair while she hears her mother and grandmother talking down the stairs. She has a music lesson at ten o'clock and she is looking forward to it. She gets out of the house from the back door so that her mother won't see her but she does and although she calls her many times Matilda does not pay her any attention. On the way to Mr. Bullen's house, her music master she has much trouble coping with the storm. But when she reaches his house she sees that everything is calm in there. She feels relieved when she sees she is not late and there is already a girl who has not finished yet.

It seems that Matilda feels very comfortable with her music master and there is no sign of the storm in his house and music room. After the girl leaves it is Matilda's turn. While Mt. Bullen 
is waiting for her to open the music satchel, she feels very worried and seems to hear and feel the wind again. While he tells her what she should practice Matilda thinks that he is very kind and without any reason she starts crying. He starts soothing her and in the middle of it Marie Swainson one of the other students comes into the room.

In the second section Matilda is at home again in her own room. The wind is blowing again and she is frightened that she is here all alone in her room and she seems to be afraid of everything in it, specially the bed. Her brother Bogey calls her and suggests they should go for a walk on the esplanade to watch the storm. They have to fight the wind until they reach the esplanade. Matilda sees a ship in the harbor and in her imagination she sees herself and brother on it, leaving behind the world-that- is for a world-that-might-be (114).

At the end Matilda and her brother are on the ship, and they are looking at the town. Years have passed and Matilda tells her brother do you remember we walked on the esplanade that windy day and I cried at my music lesson. They say goodbye to their town, and to two people who are on the esplanade. It seems that those two are Matilda and her brother at the age of puberty and they are saying goodbye to that age because a new stage is begining in their life. On the edge of puberty, Matilda the main character desires change and fears change at the same time. The opening paradox "Something dreadful has happened. No_nothing has happened. It is only the wind," suggests the tension between change and changelessness that characterizes Matilda's age (Ibid).

Disturbance is the key note of the story and all the conflicting forces of adolescence meet in her. The desire for life, for the future romantic longings and desire combined with fear of sexuality. Her inability to control these feelings is suggested through her inability to confront herself in the mirror. When she wakes at the beginning of the story she is afraid to look at herself in the mirror and later is frightened of being alone in a room where the mirror gleams at her.

It can be said that Matilda's awakening to adulthood is symbolized by the mysterious ship she and her brother, Bogey, see that is being put out to sea while walking on the esplanade:

A big black steamer with a long loop of smoke streaming, with the portholes lighted, with lights everywhere, is putting out to sea. The wind does not stop her; she cuts through the waves, making for the open gate between the pointed rocks that leads to ... It's the light that makes her look so awfully beautiful and mysterious.... (Mansfield 84)

The passage of the ship marks in the story that moment of suspension when time can either be erased or be disposed of with more freedom, which is considering it in Bergson's terms as interior time. Matilda and her brother are there on the esplanade, and at the same time they are on the ship, as adults leaving there childhood memories. This moment of suspension would free them from the burden of their time-logic fragmented structure in order to make them undertake a journey of exploration together, which is an exploration of adulthood.

\section{Conclusion}

In "Marriage a La Mode" William, regardless of the age that he is in, the condition that he is in affects his experience of time a lot. For example on his way home from London although the distance is far and he has always felt it before, this time because he is thinking of his marriage problem, he does not feel this distance anymore and is surprised that the time passed so quickly. This shows that his problems affected his time experience. These factors could also be seen in the two other stories that were analyzed. To make it short being rich or poor, happy or sad, old or 
young and finally being at ease or in disturb influences the perceiving of time in people

\section{References}

Abrams, M.H. (2005)A Glossary of Literary Terms. New York: Pearson Longman.

Alonso, Pilar R. (1996). "The Role of Intersentential Connectives in Complex Narrative Discourse: Katherine Mansfield's 'The Garden Party'." Miscelanea: A Journal of English and American Studies 17. 17-38.

Bergson, Henry. (1911).Creative Evolution. Trans. Arthur Mitchell. London: Macmillan.

--Matter and Memory. Trans. Nancy Margaret Paul, and W. Scott Palmer. London: Allen and Unwin.

(1957). Time and Freewill: An Essay on the Immediate Data of Consciousness. Arthur's Preface. London: Riverside press.

Bunyan, John. (1998). The Pilgrim's Progress. New York: Oxford University Press.

Defoe, Daniel. (1998). Robinson Crusoe. New York: Dover Publications.

Drewery, Claire. (2011). Modernist Short Fiction by Woman: The liminal in Katherine Mansfield, Dorothy Richardson, May Sinclaire and Virginia Woolf. Burlington: Ashgate Publishing Company.

Gillies, Mary Ann. (2003). "Bergsonism: 'Time out of Mind'." A Concise Companion to Modernism. Ed. Davidn Bradshaw. Malden: Blackwell, 95-115.

--.------- (1996). Henri Bergson and British Modernism. Montréal: McGill-Queen's University Press. [11]. Goethe, Johann Wolfgang Von. (2006). Faust. Trans. Bayard Taylor. New York: Echo Library.

Hanson, Clare. (1980). "The Aesthetic of Katherine Mansfield." Diss. University of Reading.

Joetze, Steffi. Literary Modernism: Katherine Mansfield and the Short Story. Norderstedt: Druck Und Bindung, (2010).

Joyce, James. A Portrait of the Artist as a Young Man. London: Penguin Books, (2000).

Kern, Stephen. The Culture of Time and Space: 1889-1918. Cambridge: Harvard UP, (2003).

Mansfield, Katherine. (2006). Collected stories of Katherine Mansfield. Hertfordshire: Wordsworth editions limited.

Mendilow, A.A. (1975). Time and the novel. London: Faber and Faber.

Meyerhoff, Hans. (1955). Time in Literature. Engleweed Cliffs: University of California Press

Morrow, Patrick D. (1993).Katherine Mansfield's Fiction. n.p. Bowling Green State University Popular Press.

Nakano, Eiko. (2005). “One or Many: Bergsonian Readings of Katherine Mansfield's Modernism.” Diss. University of Sterling.

New, William H. (1999). Reading Mansfield and Metaphors of Form. Quebec: McGill-Queen's UP.

Poulet, Georges. (1956). Studies in Human Time. London: The John Hopkins Press.

Smith, Angela. ( 2011). “'As Fastidious as though I wrote with acid': Katherine Mansfield, J.D. Fergusson and the Rhythm Group in Paris." Journal of the Katherine Mansfield Society 4-20.

Stevenson, Randall.(1992). Modernist Fiction: an Introduction. Hemel Hemstead: Harvester 